This is a self-archived version of an original article. This version may differ from the original in pagination and typographic details.

Author(s): Åkerblad, Leena; Haapakoski, Kaisa

Title: Työnantajayhteistyö ammatillisessa kuntoutuksessa ja tuetussa työllistymisessä : integroiva kirjallisuuskatsaus

Year: 2020

Version: Accepted version (Final draft)

Copyright: (C) Kuntoutussäätiö, 2020

Rights: In Copyright

Rights url: http://rightsstatements.org/page//nC/1.0/?language=en

Please cite the original version:

Åkerblad, L., \& Haapakoski, K. (2020). Työnantajayhteistyö ammatillisessa kuntoutuksessa ja tuetussa työllistymisessä : integroiva kirjallisuuskatsaus. Kuntoutus, 43(3), 20-33.

https://journal.fi/kuntoutus/article/view/100140 


\section{Työnantajayhteistyö ammatillisessa kuntoutuksessa ja tuetussa työllistymisessä. Integroiva kirjallisuuskatsaus}

\section{Tiivistelmä}

Tässä integroivassa kirjallisuuskatsauksessa selvitetään, miten ammatillista kuntoutusta ja tuettua työllistymistä koskevassa kansainvälisessä kirjallisuudessa on jäsennetty työnantajien ja työhönvalmennuksen ammattilaisten välistä yhteistyötä ja suhdetta. Keskitymme siihen, millaiset työnantajayhteistyön toimintatavat ja strategiat on nähty toimiviksi, ja miten yhteistyösuhdetta rakennetaan ja ylläpidetään. Aineiston muodostivat yksilöityjen hakukriteerien avulla valikoidut 19 tekstiä tieteellisistä aikakauslehdistä. Aineisto analysoitiin temaattisen analyysin periaatteita hyödyntäen. Analyysissa hahmottui neljä teemaa. Keskeisiä yhteistyöhön liittyviä toimintatapoja olivat jalkautuminen työnantajien maailmaan ja tämän maailman ymmärtäminen sekä molemminpuolisten hyötyjen ja yhteisten arvojen löytäminen konsultoivan työotteen avulla. Yhteistyösuhteen rakentumisen kannalta olennaista oli pitkäkestoisten suhteiden ylläpito sekä luottamus ja työhönvalmennuksen ammattilaisen saatavilla olo. Tärkeää oli myös yhteistyötä tukevien resurssien riittävyyden varmistaminen ja resurssien vahvistaminen palveluita tuottavissa organisaatioissa. Tulosten merkitys: Tulokset osoittavat, että kuntoutuksen ammattilaisten ja työnantajien välistä yhteistyötä voidaan edistää strategioilla, joissa keskeistä ovat yhtäaikaisesti toisiaan täydentävät tarjonta- ja kysyntäpainotteiset sekä tukeen perustuvat lähestymistavat. Tulosten perusteella yhteistyön mahdollistamisessa on olennaista molemminpuolisten hyötyjen tunnistaminen, pitkäjänteisyys sekä palveluita tuottavien systeemien kyky tarjota työhönvalmennuksen ammattilaisille välineitä ja resursseja yhteistyön toteuttamiseen.

Avainsanat: Ammatillinen kuntoutus, työhönvalmennus, tuettu työllistyminen, työnantajayhteistyö 


\section{Johdanto}

Työhönvalmennusta sisältävälle ammatilliselle kuntoutukselle ja tuetulle työllistymiselle on leimallista se, että työnantaja voidaan nähdä kuntoutuksen aktiivisena osapuolena samalla tavoin kuin palveluiden osallistuja ja palveluja tuottava yksikkö. Mooren ym. (2018) mukaan ammatillisen kuntoutuksen ajankohtaisissa kehityssuunnissa painottuvat kaksoisasiakkuuteen (dual customer) perustuvat näkökulmat, joissa kuntoutuksen katsotaan palvelevan sekä osatyökykyisiä että työnantajaorganisaatioita. Tamburo ym. $(2019,291)$ toteavat, että työnantajien sitouttamisen strategiat ovat tärkeitä laadukkaan tuen tarjoamisessa osatyökykyisille. Luottamukselliset suhteet kuntoutuksen eri osapuolten välillä mahdollistavat räätälöidyn tuen tarjoamisen ja lisäävät työnantajien luottamusta osatyökykyisten työllistettävyyteen (Strindlund ym. 2019). Kansainvälisesti runsaasti tutkittu ja sovellettu, näyttöön perustuva tuetun työllistymisen IPS-malli (individual placement and support) edellyttää suhteiden luomista työnantajiin ja työskentelyä työnantajien kanssa asiakkaiden preferenssien pohjalta (Drake, Bond \& Becker, 2012). Tällä hetkellä IPS-malli ei ole Suomessa laajasti käytössä, mutta valtio on lähtenyt tukemaan sen käyttöönoton mahdollisuuksia (ks. Raivio \& Appelqvist-Schmidlechner 2019; 2020).

Työnantajien näkemyksiä osatyökykyisten työllistymistä edistävistä, työpaikoille sijoittuvista palveluista on selvitetty Suomessa jonkin verran. Härkäpään ym. (2013) tutkimuksessa tarkasteltiin suomalaista työhönvalmennustoimintaa ja myös työnantajien näkemyksiä tästä toiminnasta. Kirjoittajien mukaan työnantajat näkivät mahdollisuuksia erityisesti pidempikestoisessa valmennuksessa. Moni työnantaja tuntee kuitenkin heikosti erilaisia tukimahdollisuuksia (Härkäpää \& Järvikoski 2013). Härkäpään ja Järvikosken (2013) mukaan työnantajat ovat vastaanottavaisia työvalmentajan tuelle, ja aktiivinen yhteistyö voi mahdollistaa osatyökykyisen henkilön työllistymisen haastavastakin elämänhistoriasta huolimatta. Karhu (2013) on tarkastellut vajaakuntoisten henkilöiden työllistämisen ja tuetun työllistymisen merkitystä työnantajien näkökulmasta. Hänen mukaansa työllistämiseen liittyy työnantajien näkökulmasta useita tekijöitä: yhteiskunnallinen tuki, yksilölliset ominaisuudet, organisaation rakenteelliset ja taloudelliset puitteet sekä työnantajan ja työyhteisön asenne. Työllistämisen todennäköisyys työnantajalla kasvaa, jos mainitut osa-alueet ovat tasapainossa suhteessa toisiinsa 
(Karhu 2013). Kukkonen (2009) puolestaan kiinnittää huomiota työn räätälöinnin kysymyksiin, jotka vaikuttavat hänen mukaansa keskeisesti vajaakuntoisten työllistämistä koskevaan harkintaan ja päätöksentekoon. Työnantajat voivat kokea räätälöinnin vaikeaksi ja ennakoivat, että vajaakuntoisen henkilön rekrytoinnista seuraa siihen liittyviä haasteita. Työn räätälöintiin liittyvää osaamista ja sitä tukevia palveluita olisikin Kukkosen (2009) mukaan tarpeen kehittää.

Kansainvälisesti työnantajien näkemykset tuetusta työllistymisestä ja työnantajayhteistyön käytännöt ovat olleet suhteellisen harvoin tutkimuksen kohteena (esim. Carlson ym. 2018; Ellenkampf ym. 2016; Lexén ym. 2016; Tamburo ym. 2019). Palvelujen kehittämiseksi tarvitaan kuitenkin tietoa siitä, miten työnantajat kokevat työpaikoille sijoittuvat palvelut ja millaiset työnantajayhteistyön strategiat ovat osoittautuneet toimiviksi ja missä kontekstissa. Nämä strategiat kytkeytyvät myös laajempiin työelämäinkluusion edistämisen tavoitteisiin. Työnantajalähtöiset (employer-focused) käytännöt osatyökykyisten työllistymisen tukemisessa eivät edistä ainoastaan työnantajasuhteiden luomista, vaan pitkällä tähtäimellä osatyökykyisten työllistymismahdollisuuksia myös laajemmin (Harris ym. 2017, Tamburo ym. 2019).

Tämän integroivan kirjallisuuskatsauksen tavoitteena on selvittää, miten ammatillista kuntoutusta ja tuettua työllistymistä koskevassa kansainvälisessä kirjallisuudessa on jäsennetty työnantajien ja palveluntuottajien tai kuntoutuksen ammattilaisten välistä yhteistyösuhdetta. Fokusoimme erityisesti suhteen luomisen ja ylläpidon keskeisiin elementteihin sekä yhteistyötä edistäviin strategioihin ja toimintatapoihin. Yleisesti katsaus kiinnittyy työnantajien osallistamisen (employer engagement) strategioihin ammatillisen kuntoutuksen ja tuetun työllistymisen (supported employment) kontekstissa. Tämä konteksti sisältää sekä erilaisia osatyökykyisille suunnattuja tuetun työllistymisen malleja, että yksittäisten palvelujen rajat ylittäviä toimintatapoja, joissa työskennellään osatyökykyisten lisäksi työnantajien kanssa. Malleja ja toimintatapoja yhdistää se, että niissä painotetaan työskentelyä ulkopuolisessa työpaikassa ja tavoitteena on palveluihin osallistuvan työllistyminen avoimille työmarkkinoille (competitive employment). 


\section{Ammatillisen kuntoutuksen lähestymistavat ja tuettu työllistyminen Suomessa}

Härkäpään ym. $(2013,17)$ mukaan suomalainen ammatillinen kuntoutus on keskittynyt erityisesti työvoiman tarjontaan vaikuttavaan strategiaan kuten työnhakijan valmiuksiin vaikuttamiseen (ks. Järvikoski ja Härkäpää 2004, 195-197). Tarjontapainotteisissa ammatillisen kuntoutuksen lähestymistavoissa (supply-side approach) painotetaan työnhakijan kouluttamista ja työhön sijoittamista, tiedon tarjoamista sekä työpaikan ja kuntoutujan välisen yhteyden fasilitointia (Frøyland ym. 2019a; Luecking 2008). Työnantajien ja työmarkkinoiden vaatimukset nähdään joustamattomina ja työkyky yksilön ominaisuutena. Lisäksi tarjontapainotteisissa lähestymistavoissa lähdetään oletuksesta, että työpaikkoja todella on olemassa. (Frøyland ym. 2019a.) Toinen ammatillisen kuntoutuksen perusstrategia perustuu työvoiman kysyntään vaikuttamiseen eli sellaisten työmarkkinaolosuhteiden luomiseen, jotka lisäävät kiinnostusta kuntoutujan työpanokseen (Järvikoski \& Härkäpää 2004, 195-197). Tämä strategia on Härkäpään ym. $(2013,17)$ mukaan jäänyt suomalaisessa ammatillisessa kuntoutuksessa vähemmälle huomiolle.

Kysyntäpainotteisissa ammatillisen kuntoutuksen lähestymistavoissa (demand-side approach) tarjotaan palveluja myös työnantajille. Työnantajia autetaan ratkaisemaan työvoiman kysyntään liittyviä tarpeitaan sekä muokkaamaan työympäristöä osatyökykyisille saavutettavaksi (esim. Luecking 2008). Lähestymistapa voi sisältää ajatuksen molemminpuolisesta hyödystä ja kaksoisasiakkuudesta (ks. Moore ym. 2018). Buys ja Rennie $(2001,96)$ toteavat, että työnantajien ja kuntoutuksen palveluntuottajien välinen kumppanuussuhde (partnership) on esimerkki kysyntäpainotteisesta lähestymistavasta. Frøyland ja kumppanit (2019a, 312) kirjoittavat myös yhdistetyistä, työpaikkaorientoituneista lähestymistavoista (combined workplace-oriented approaches) sekä yhtäaikaiseen tukeen perustuvista lähestymistavoista (support side approaches) (Frøyland ym. 2019b, 194). Tuetun työllistymisen (supported employment) mallit voivat Frøylandin ja kumppaneiden (2019a, 2019b) mukaan edustaa näitä lähestymistapoja. Yhdistetyissä lähestymistavoissa painopiste on työpaikalla tapahtuvassa prosessissa, ja työpaikat käsitetään työelämäintegraation instrumenteiksi. Työkyky nähdään prosessina ja relationaalisena käsitteenä. Työpaikat, työelämän rakenteet, kulttuurit ja arvot nähdään puolestaan joustavina ja muokattavina. Työelämän muokattavuus mahdollistaa myös 
työpaikkojen luomisen ja niiden sopeuttamisen työntekijöiden tarpeisiin. Näin ollen työelämäintegraatio voidaan saavuttaa nimenomaan yhteistyössä työnantajien kanssa ja heitä tukien. (Frøyland ym. 2019a.)

Härkäpään ja kumppaneiden $(2013,9)$ mukaan Suomessa toteutettu työhönvalmennustoiminta on lähellä tuettua työllistymistä (supported employment). Kuitenkin esimerkiksi Pikkusaari (2016) huomauttaa, että varsinaista tuetun työllistymisen lähestymistapaa ei ole suomalaisessa järjestelmässä hyödynnetty riittävästi, etenkään osana ammatillisen kuntoutuksen järjestelmää. Työhönvalmennus sinänsä kuuluu sekä ammatillisen kuntoutuksen että vaikeasti työllistyvien työllistämistoimenpiteisiin. Sitä toteuttavat Kela, työeläkelaitokset ja TE-hallinto sekä kunnat ja kuntayhtymät. Työhönvalmennusta järjestetään myös erilaisissa hankkeissa ja projekteissa. (Härkäpää ym. 2013, 9-10.) Vuonna 2012 toteutetussa eurooppalaisessa vertailussa todettiinkin, että Suomessa toteutetaan varsin monenlaisia tuetun työllistymisen projekteja, ja ongelmana on yhteisen määritelmän puute (Publications Office of the EU 2012, 78). Suomessa on nähty tarpeelliseksi kehittää myös tuettuun työllistymiseen liittyvää ammatillista perustaa (Härkäpää 2005) sekä turvata ostopalveluun perustuvassa järjestelmässä järjestäjän resurssit toteuttaa palvelua työnantajayhteistyötä mahdollistavalla tavalla (Nupponen 2016).

Tuetun työllistymisen näyttöön perustuva IPS-toimintamalli ei ole ollut Suomessa laajasti käytössä, mutta sen mahdollisuuksista on tehty selvitys (ks. Raivio \& Appelqvist-Schmidlechner 2019). Jatkossa sitä on tarkoitus kehittää ja mallintaa valtion rahoituksella tuetuissa hankkeissa (ks. Raivio \& Appelqvist-Schmidlechner 2020). Myös Kelan ammatillinen kuntoutus on sisältänyt vuodesta 2017 alkaen työllistymistä edistävää ammatillista kuntoutusta, jonka toteutuksessa on huomioitu joitain mallille keskeisiä piirteitä kuten avoimille työmarkkinoille suuntautuminen ja nopea työn etsintä (Haapakoski ym. 2020).

Tämän katsauksen aineisto muodostuu kansainvälisistä, englanninkielisistä teksteistä. Näin on mahdollista pohtia, miten ja mitkä kansainväliset työnantajasuhteisiin liittyvät strategiat ja toimintatavat voisivat olla hyödyllisiä Suomen kontekstissa. Toisaalta on tärkeää tunnistaa, että ammatillista kuntoutusta ja tuettua työllistymistä toteutetaan osana monia erilaisia yhteiskuntia, lainsäädäntöjä, palvelujärjestelmiä ja työmarkkinoita sekä hyvin monissa eri muodoissa. 
Osatyökykyisten työllistymistä edistäviin, työpaikoille sijoittuviin toimenpiteisiin ja palvelumalleihin liittyvä terminologia on niin ikään vaihtelevaa. Näiden seikkojen vuoksi synteesin tekemisessä on haasteensa. Suuntasimmekin analyysin erityisesti tekstejä yhdistäviin, ylemmän tason teemoihin.

\section{Aineisto ja menetelmät}

\section{Tutkimustehtävä}

Tässä katsauksessa selvitetään, miten ammatillisen kuntoutuksen ja tuetun työllistymisen tutkimuksessa ja kirjallisuudessa on jäsennetty työnantajien sekä palveluntuottajien ja kuntoutuksen ammattilaisten välistä suhdetta ja yhteistyötä. Kysymykset ovat seuraavat: Millaiset työnantajayhteistyön (cooperation, collaboration) strategiat ja toimintatavat nähdään työpaikoille sijoittuvissa ammatillisen kuntoutuksen ja tuetun työllistymisen palveluissa toimiviksi? Mitkä tekijät nähdään toimivan yhteistyösuhteen (partnership) luomisen ja ylläpidon keskeisiksi elementeiksi? Tarkastelu kohdistettiin laajasti ammatilliseen kuntoutukseen ja tuettuun työllistymiseen, jotka sisältävät erilaisia palvelumalleja ja toimintatapoja.

\section{Aineisto ja menetelmät}

Katsaus toteutettiin integroivana kirjallisuuskatsauksena, jossa voidaan hyödyntää käsiteltävän aiheen kannalta monenlaista kirjallisuutta ja tutkimusta (ks. Whittemore \& Knafl 2005). Tämä oli tärkeää siksi, että aihetta koskevia tutkimuksia on tehty määrällisesti suhteellisen vähän. Samasta syystä mukaan otettiin myös hieman vanhempia tekstejä. Integroivassa kirjallisuuskatsauksessa aineisto muodostuu tutkimusaiheen kannalta merkityksellisestä tutkimustiedosta, ja katsaus sisältää kuvauksen aineiston valinnan prosessista (Grant \& Booth 2009; Torraco 2016). Ennen varsinaisia kirjallisuushakuja toteutimme alustavan kartoituksen.

Siinä teimme koehakuja kirjaston aineistoista ja kansainvälisisistä tietokannoista sekä keräsimme yhteen jo tiedossamme olevia tekstejä. Kävimme alustavia hakutuloksia läpi otsikko- ja abstraktitasolla. Vastaan tulleiden tekstien ja hakutulosten avulla täsmensimme tutkimuskysymyksiä ja hakutermejä. Ennen integroivan kirjallisuuskatsauksen aloittamista onkin 
olennaista, että katsauksen kohteet muotoillaan selkeiksi ja strukturoiduiksi kysymyksiksi (Hopia ym. 2016; Whittemore \& Knafl 2005). Tutkimuskysymyksiin jätettiin riittävää käsitteellistä väljyyttä, jotta ilmiötä olisi mahdollista tarkastella monista, ehkä myös yllättävistä kulmista (ks. Hopia ym. 2016).

Valitsimme kansainvälisen aineiston hakuun kaksi laajempaa hakutermiä: vocational rehabilitation ja supported employment. Näihin yhdistimme tutkimuskysymysten kannalta olennaisia, tarkempia avainsanoja: employers; collaboration OR cooperation OR relations OR relationships. Teimme haut EBSCO Academic Search Elite sekä ProQuest (Social Services Abstracts) tietokantojen akateemisista journaaleista vuosilta 1980-2020. Otimme mukaan monentyyppisiä tekstejä: teoreettisia ja empiirisiä artikkeleita, katsauksia sekä puheenvuoroja. Haut tuottivat (kaksoiskappaleiden poiston jälkeen) 368 tulosta. Luimme tekstit otsikko- ja abstraktitasolla, ja mukaan valikoitui alustavasti 85 tekstiä (EbscoHost 74 kpl; ProQuest 11 kpl). Lisäksi etsimme tekstejä niin sanotulla lumipallomenetelmällä, kuten keskeisten artikkeleiden lähdeluetteloista. Tällä menetelmällä tekstejä löytyi 19.

Luimme nämä 104 tekstiä kokonaan, ja niistä valikoitui lopulliseen aineistoon 19. Aineiston tarkemmat sisäänotto- ja poissulkukriteerit esitetään taulukossa 1 ja aineisto esitellään liitteessä 1. Empiirisiä tutkimuksia oli yhdeksän (menetelmänä yksilöhaastattelut, fokusryhmähaastattelut, survey ja kvasikokeellinen asetelma). Lisäksi mukana oli tapauskuvauksia, suppeampia katsauksia, puheenvuoroja sekä käytännönläheisiä raportteja (ks. liite 1). Kaikki tekstit kiinnittyivät ammatilliseen kuntoutukseen (vocational rehabilitation), tuettuun työllistymiseen (supported employment) tai johonkin niihin liittyvään toimintamalliin (customized employment, job development). Osa teksteistä käsitteli yleisemmin työnantajien käsityksiä osatyökykyisten palkkaamisesta, mutta niissä esitettiin suosituksia tai johtopäätöksiä palvelujen ja toimintamallien näkökulmasta.

Aineiston valinnassa tärkeänä kriteerinä pidettiin sitä, että pystymme valittujen tekstien avulla tarkastelemaan tutkimuskohdetta ilmiölähtöisesti ja tarkoituksenmukaisesti suhteessa tutkimuskysymyksiin (ks. esim. Polit \& Beck 2012). Tekstien laadukkuus pyrittiin varmistamaan käyttämällä luotettavia tietokantoja ja arvioimalla tekstejä sekä valinta- että analyysivaiheessa. 
Kiinnitimme huomiota erityisesti mahdollisen aineistonkeruun ja käytettyjen menetelmien kuvaamiseen sekä julkaisufoorumiin.

Taulukko 1. Aineiston sisäänotto- ja ulossulkukriteerit

\begin{tabular}{|l|l|}
\hline Sisäänottokriteerit & Ulossulkukriteerit \\
\hline $\begin{array}{l}\text { - Julkaistu vuosina } 1980-2020 \\
\text { - Kieli englanti }\end{array}$ & - Alemmat opinnäytetyöt \\
- VR/SE-konteksti & Ei selvää VR/SE-kontekstia \\
- Keskitytään työnantajien kanssa tehtävään & - Käsitellään spesifiin kansalliseen \\
yhteistyöhön tai kumppanuus- tai & kontekstiin ja ajankohtaan kiimnittyviä \\
yhteistyösuhteeseen & yksittäisiä ohjelmia tai projekteja \\
- Tarkastellaan yhteistyöhön liittyviä & Kansallisten lakimuutosten politiikkatason \\
strategioita ja toimintatapoja & tarkastelut \\
- Käsitellään palveluntuottajien tai & Koulutusta koskevat tekstit \\
organisaatioiden valmiuksia yhteistyöhön, & - Tarkastellaan työnantajien asenteita \\
yhteistyön esteitä tai yhteistyöhön & osatyökykyisiä tai spesifejä \\
vaikuttavia tekijöitä & osatyökykyisten ryhmiä kohtaan ilman \\
& kiinnityspintaa tutkimuskysymyksiin \\
\hline
\end{tabular}

Tavoitteenamme oli vastata tutkimuskysymyksiin harkitusti valikoidun aineiston tuottamana laadullisena kuvailuna (ks. Rother 2007, Grant \& Booth 2009). Integroivassa katsauksessa kuvauksen rakentamisessa käytetään usein laadullisen tutkimuksen menetelmiä (Grant \& Booth 2009). Hyödynsimme analyysissa temaattisen analyysin periaatteita. Temaattinen analyysi muodostuu prosessista, jossa aineistosta tunnistetaan tutkimustehtävän kannalta tärkeitä tai kiinnostavia "kaavoja" (pattern) ja teemoja (Braun \& Clarke 2006). Analyysi aloitetaan aineiston holistisella lukemisella (Braun \& Clarke 2006). Jaoimme aineistoksi valikoituneet 19 tekstiä tutkijoiden kesken, luimme ne kokonaisuutena ja teimme niistä tiivistelmät. Sisällytimme tiivistelmiin kussakin tekstissä esiin nostetut keskeisimmät havainnot ja tutkimuskysymysten kannalta tärkeät johtopäätökset.

Toinen tutkijoista hahmotteli alustavan teemarungon kiinnittäen huomiota erityisesti toistuviin teemoihin, jotka liittyivät toimintatapoihin, strategioihin ja toimivan yhteistyösuhteen elementteihin. Analyysi ei kohdistunut ainoastaan tutkimustuloksiin vaan myös johtopäätöksiin ja suosituksiin sekä teksteissä esiintyviin näkökulmiin ja lähestymistapoihin. Huomiota kiinnitettiin temaattisen analyysin mukaisesti myös teemojen välisiin suhteisiin (ks. Castleberry 
\& Nolen 2018). Teemarunkoon pyrittiin sisällyttämään kaikki tutkimuskysymysten kannalta keskeiset havainnot. Jotta teemoittelu olisi mahdollisimman kattavaa, toinen tutkijoista tarkisti rungon ja täydensi sitä. Lopuksi palasimme teksteihin kokonaisuutena ja yhdistimme teemoja laajemmiksi kokonaisuuksiksi. Pyrimme luomaan aineistosta jäsentyneen kokonaisuuden, joka on integroivalle kirjallisuuskatsaukselle ominainen tavoite (ks. Fitzgerald \& Rumrill 2005; Torraco 2016). Seuraavissa luvuissa esittelemme analyysin pohjalta hahmottuneet teemat.

\section{Tulokset}

\section{Jalkautuminen työnantajien maailmaan ja tämän maailman ymmärtäminen}

Työpaikoille sijoittuvan ammatillisen kuntoutuksen ja tuetun työllistymisen toimintaympäristö sisältää erilaisia ja erilaisilla logiikoilla operoivia toimijoita. Aineistossa korostetaan sitä, että työnantajayhteistyön edistämiseksi palveluja tuottavien tulisi olla tietoisia työpaikkojen toimintaympäristöistä ja oppia ymmärtämään niitä. Myös valmentajien ymmärrys heidän oman organisaationsa toiminnasta ja organisaation tarjoamien palvelujen markkinoista on yhteistyön mahdollisuuksien kannalta olennaista (Anderson 2001). Kuntoutuksen ammattilaisten on hyvä tuntea myös yleisesti työmarkkinoita ja työmarkkinatrendejä sekä tarkemmin oman alueensa työnantajia ja yrityksiä (Anderson 2001; Buys \& Rennie 2001; Henry ym. 2014). Paikallisten

yritysten tuntemus auttaa tunnistamaan työnantajia, jotka omaavat inklusiivisia arvoja ja kantavat yhteiskuntavastuuta (Buys \& Rennie 2001; Simonsen 2011). Ymmärrykseen perustuvan yhteistyön rakentamista edistää myös se, että kuntoutuksen ammattilaiset tutustuvat käytännön tasolla yritysten toimintaan. Valmentajien tulee ottaa selvää yritysten kulttuurista (Anderson 2001; Fry 1998; Buys \& Rennie 2001), selvittää kunkin yrityksen missiot, tavoitteet ja työvoimatarpeet (Henry ym. 2014) sekä perusfilosofia ja liiketoiminnan ydin (Anderson 2001).

Lueckingin (2008) mukaan ammatillisen kuntoutuksen toteuttajat voidaan nähdä liike-elämän kentällä passiivisina toimijoina, jotka eivät tunne kentän käytäntöjä. He eivät välttämättä ole osallisina erilaisissa liike-elämän kumppanuussuhteissa ja koalitioissa (Harris ym. 2017). Verkostoituminen paikallisiin yrityksiin ja ylipäätään työnantajien maailmaan on yhteistyön rakentamisessa tärkeää (Capella McDonnall \& Crudden 2015; Henry ym. 2014; Luecking 2008). 
Aineistossa keskeinen näkökulma on se, että tähän maailmaan jalkautuminen antaa sekä tietoa työnantajien tarpeista ja odotuksista, että osoittaa kiinnostusta työnantajia kohtaan. Työnantajan luottamusta lisää tunne siitä, että kuntoutuksen ammattilainen ymmärtää hänen liiketoimintaansa (Swanson 2013).

Swanson ym. (2013) näkevät kasvokkaiset tapaamiset kuntoutuksen ammattilaisten ja työnantajien välisen suhteen tärkeinä ensiaskelina. Monissa aineiston teksteissä esitellään joskus varsin yksityiskohtaisesti - erilaisia kontaktin ottamiseen ja tapaamisiin liittyviä käytäntöjä. Nämä eivät kuitenkaan ongelmitta käänny toiseen järjestelmään ja ajalliseen kontekstiin. Yleisellä tasolla teksteissä tuodaan esiin, että valmentajien kannattaa perehtyä yritykseen etukäteen (Swanson ym. 2018; Post ym. 2010). Tapaamisissa on tärkeää osoittaa kiinnostusta työnantajaa kohtaan; avointen kysymysten esittäminen ja kartoittava haastattelu (informational interview) mainitaan hyödyllisinä menetelminä (Griffin ym. 2008: Henry ym. 2014; Simonsen ym. 2011; Post ym. 2010). Ylipäätään kontaktoinnissa ja tapaamisissa olisi hyvä hyödyntää strategioita, jotka auttavat oppimaan enemmän kustakin työnantajasta (Riesen \& Morgan 2018).

Tekstien mukaan viestintä ja vuorovaikutus vaikuttavat siihen, missä määrin työnantajat voivat kokea tulevansa ymmärretyiksi. Teksteissä viitataan usein "työnantajiin resonoiviin" puhe- ja toimintatapoihin. Viestinnän ja vuorovaikutuksen tulee soveltua liike-elämään, ja kuntoutuksen ammattilaisten kannattaa käyttää työnantajiin resonoivaa, "bisnesorientoitunutta” puhetapaa (Simmons \& Flexer 1992; Simonsen ym. 2011) sekä välttää “kuntoutusjargonia” (Post ym. 2010). Henry ym. (2014) toteavat, että palvelut tulisi ylipäätään kehystää työnantajien toimintaan resonoivalla tavalla: esimerkiksi osoittamalla, miten palvelu voi tuottaa hyötyjä liiketoiminnalle luomalla monimuotoista työvoimaa yrityksen tarpeisiin. Owens-Johnsonin (1998) ja Ungerin (2007) mukaan viestintuojana kannattaa käyttää työnantajille merkityksellisiä tahoja, kuten muita työnantajia. Työnantajat kaipaavat esimerkkejä hyvistä käytännöistä ja roolimalleja (Simmons \& Flexer 1992) sekä esimerkkejä (Henry ym. 2014; Riesen \& Morgan 2018). Simmonsin ja Flexerin (1992) mukaan myös osatyökykyisiä on hyvä käyttää kertojina. Toisaalta Luecking (2008) varoittaa, että stereotyyppiset tarinat "supersuoriutuvista" osatyökykyisistä voivat olla myös haitallisia. 


\section{Molemminpuolisten hyötyjen ja yhteisten arvojen löytäminen}

Tarjontapainotteista (demand-side) ammatillisen kuntoutuksen lähestymistapaa käsittelevissä teksteissä tehdään erontekoa ajatteluun, jossa työnantajille myydään tuotetta, asiakasta tai palvelua (Luecking 2008; McDonnall ym. 2015; Simonsen ym. 2011). Lähestymistapaan liittyy idea siitä, että on tehokkaampaa selvittää työnantajien tarpeet ja sovittaa palvelut tähän, kuin vakuutella työnantajaa ostamaan palveluja tai palkkaamaan osatyökykyisiä (Luecking 2008). Tarjontapainotteiseen lähestymistapaan liittyy enemmänkin markkinoinnin (marketing) kuin myynnin (selling) kieli. Simonsen ym. (2011) toteavat, että markkinoinnin lähtökohtana on lisäarvon tuottaminen työnantajalle, eikä osatyökykyisten palkkaamisen konseptin myynti. Myynnillinen lähtökohta ei kirjoittajien mukaan edistä työnantajien tarpeiden tunnistamista, vaan heijastaa tarjontalähtöistä ( supply-side) lähestymistapaa. Markkinointi nähdään ennen kaikkea vaihtona (Anderson 2001; Owens-Johnson \& Hanley-Maxwell 1999).

Työnantajia lähestytään tietynlaisessa konsultin roolissa, rakentaen suhdetta ja luoden tätä kautta mahdollisuuksia (Andersson 2001; Griffin ym. 2018; Luecking 2008; McDonall ym. 2015). Kuntoutuksen ammattilaisten ja työnantajien välisen yhteistyösuhteen lähtökohtana on molemminpuolisten hyötyjen ja jaettujen arvojen löytäminen ja painottaminen (Anderson 2001; Buys \& Rennie 2001; Luecking 2008; Strindlund ym. 2019) ja sekä palveluihin osallistuvan että työnantajan näkeminen asiakkaina (Kukla ym. 2018). Konsultoiva ote tuntuu vaativan kuntoutuksen ammattilaiselta sekä tietynlaista havainnointikykyä ja luovuutta, että perehtymistä työnantajan tarpeisiin ja yrityksen toimintaan. Tutustumalla yritykseen ja ajattelemalla luovasti valmentaja voi löytää palveluihin osallistuville niin sanottuja piilotöitä (Buys \& Rennie 2001; Luecking 2008). Tällaisilla tarjonta- ja kysyntäpainotteisia lähestymistapoja yhdistelevillä toimintatavoilla voidaan lisätä työvoiman kysyntää ja tuottaa hyötyjä kaikille osapuolille (Luecking 2008).

Aineistossa nostetaan esiin, että työnantajalle koituvat hyödyt on etsittävä yrityskohtaisesti. Henry ym. $(2014,244)$ toteavat, että lähtökohtana tulisi olla seuraava kysymys: miten edustamani ihmiset ja palvelut voivat auttaa tätä yritystä saavuttamaan tavoitteensa? Kyse on 
niin sanotusta arvolupauksesta tai arvoehdotuksesta (value proposition), johon Riesen ja Morgan (2018) sekä Tamburo ym. (2019) viittaavat. Lähtökohtana on se, että tietyillä toimilla ja palveluilla voidaan säästää työnantajan kustannuksia - ja lisätä näin palvelujen kysyntää (Anderson 2001; Luecking 2008). Yhteistyö itsessään kannattaa toteuttaa työnantajien resursseja säästävällä tavalla, jolloin työskentelyssä kunnioitetaan työnantajan lähtökohtia, aikaa ja prioriteetteja (Kukla ym. 2018) sekä pidetään prosessi selkeänä ja kustannustehokkaana (Fry 1998).

Molemminpuolisten hyötyjen lisäksi joissain teksteissä viitataan jaettuihin arvoihin. Yhteistyösuhteen rakentamisessa voidaan hyödyntää osapuolille yhteisiä organisatorisia arvoja liittyen esimerkiksi diversiteettipolitiikkaan ja osatyökykyisten inkluusioon (Unger 2007). Jo yhteydenottovaiheissa osatyökykyisyyteen liittyvät kysymykset voidaan kytkeä laajempiin monimuotoisuutta (diversity) korostaviin työpaikkanäkökulmiin (Post ym. 2010). Tässä lähestymistavassa nousevat esiin osatyökykyisten työllistymisen palvelujen ja työnantajien kosketuspinnat ja "jaetut tilat”. Harris ym. (2017) toteavat, että osatyökykyiset, työnantajat ja kuntoutuksen ammattilaiset toimivat erilaisesta kulttuurisesta kontekstista ja perspektiivistä käsin. Näin ollen yhteistyön mahdollisuudet syntyvät löytämällä jaettuja tiloja näiden perspektiivien väliltä (Harris ym. 2017).

\section{Pitkäkestoisten suhteiden ylläpito, luottamus ja saatavilla olo}

Erään aineistossa esiintyvän näkökulman mukaan työnantajayhteistyössä on kyse ennen kaikkea pitkäkestoisten suhteiden luomisesta ja ylläpidosta (Anderson 2001; Buys \& Rennie 2001; Capella McDonnall \& Crudden 2015). Nämä suhteet mahdollistavat osaltaan työnantajan tarpeiden tunnistamisen, jolloin valmentaja voi tehdä muutakin kuin myydä palvelua tai asiakkaita (Capella McDonnall \& Crudden 2015). Capella McDonnallin ja Cruddenin (2015) mukaan ajatus suhteiden rakentamisesta ja työnantajien ymmärtämisestä sopii hyvin valmentajille, koska se vertautuu työskentelyyn palveluihin osallistuvien kanssa.

Monissa teksteissä korostetaan kuntoutuksen ammattilaisten ja työnantajien väliseen suhteeseen liittyvää luottamusta (Buys \& Rennie 2001; Capella McDonnall \& Crudden 2015; Fry 1997; 
Simonsen ym. 2011; Strindlund ym. 2019). Buys ja Rennie (2001) näkevät, että palveluntuottajan luotettavuus ja tätä osoittavat johdonmukaiset ja responsiiviset toimintatavat ovat yhteistyön rakentamisessa tärkeitä. Valmentajan on oltava tavoitettavissa ja tarjottava tukea sekä työnantajalle että työntekijälle koko prosessin ajan (Buys \& Rennie 2001; Capella McDonnall \& Crudden 2015; Luecking 2008; Simonsen 2011). Strindlundin ym. (2019) mukaan tämän tuen on oltava riittävää, dynaamista ja tilanteeseen sopivaa. Nimenomaan pitkäaikainen suhde työnantajaan mahdollistaa tuen räätälöinnin - ja räätälöity tuki puolestaan vahvistaa työnantajien luottamusta osatyökykyisiin ja lisää näin työelämäinkluusiota (Strindlund ym. 2019).

Yhteistyösuhteen ylläpitoa edistävät muun muassa yhdessä vietetty aika ja työnantajien hyväksi kokema palvelu (Buys \& Rennie 2001). Toisaalta kyse ei ole ainoastaan asiakastyytyväisyydestä, sillä kumppanuussuhteet perustuvat myös rehellisyydelle ja ymmärrykselle. Buys ja Rennie (2001) käsittelevät muista teksteistä poiketen myös työnantajan vastuuta suhteen rakentamisessa; heidän mukaansa työnantajilta edellytetään sitoutumista ja rehellistä kommunikaatiota. Monissa teksteissä tuodaan myös esiin, että kyse on usein henkilökohtaisesta suhteesta valmentajan ja työnantajan edustajan välillä (Buys \& Rennie 2001; Capella McDonnall \& Crudden 2015; Kukla ym. 2018; Simonsen ym. 2011). Näin ollen henkilöstövaihdokset saattavat hankaloittaa suhteen ylläpitämistä (Capella McDonnall \& Crudden 2015; Tamburo ym. 2019). Henkilökohtaista luottamuksellista suhdetta on vaikeaa "siirtää" seuraavalle työntekijälle.

\section{Yhteistyötä tukevien resurssien varmistaminen ja vahvistaminen}

Ammatillisen kuntoutuksen ja tuetun työllistymisen palveluja toteuttavat ammattilaiset tarvitsevat resursseja ja tukea työnantajasuhteiden luomiseksi ja ylläpitämiseksi. Tätä painotetaan erityisesti aineiston uudemmissa teksteissä. Organisaatiotasolla valmentajien kapasiteettia voidaan tukea tarjoamalla koulutusta (Buys \& Rennie 2001). Tamburo ym. (2019) puolestaan viittaavat niiden organisaation jäsenten hyödyntämiseen, joilla on tietoa asiasta sekä siihen, että työntekijät kaipaavat konkreettisia työkaluja. Myös johdon tarjoama tuki ja ohjaus ovat tärkeitä (Kukla ym. 2018; Tamburo ym. 2019). Swansonin ym. (2013) mukaan esimiehen tulee nähdä työnantajasuhteiden luominen ja ylläpitäminen osana valmentajien työtä. Kukla ym. (2018) 
toteavat, että johdon tulee jakaa strategioita yhteistyösuhteen luomiseen ja ylläpitämiseen - mutta tarjota myös tarpeellisia työvälineitä ja aikaresursseja. Organisaatioissa voidaan myös luoda spesifejä toimenkuvia työnantajasuhteiden koordinointiin ja markkinointiin liittyen (Henry ym. 2014). Yhteistyötä tukevina organisaatiotason keinoina mainitaan asiakastyytyväisyyden ja työnantajasuhteiden mittaamisen tavat sekä ajantasaiset työnantaja- ja työnhakijarekisterit. Kyse ei ole kuitenkaan ainoastaan konkreettisista välineistä tai keinoista. Tamburon ym. (2019) mukaan organisaatioissa tarvitaan myös asennemuutosta.

Palveluntuottajien keskinäinen verkostoituminen voi osaltaan edistää työnantajayhteistyötä. Henry ym. (2014) toteavat, että useat yhteydenotot eri palveluntuottajilta aiheuttavat sekaannusta ja kuormittavat työnantajia. Palveluja itsessään tulisi mukauttaa kontekstiin (Unger 2007) ja tarjota työnantajien tarpeisiin kustomoituja, tehokkaita ja yksinkertaisia palveluja (Anderson 2001). Myös yleinen rahoitus asiakas- tai sijoituskohtaisen rahoituksen sijaan voisi tukea työnantajayhteistyötä (Owens-Johnson ym. 1998). Politiikkatasolla muutos perustuu ajatukselle, että muutos on ylipäätään mahdollista, ja käytännön tasolla tapahtuva toiminta muovaa osaltaan myös politiikkatasoa eli työmarkkinatason integraatiota (Harris ym. 2017).

\section{Johtopäätökset}

Tämän integroivan kirjallisuuskatsauksen perusteella työpaikkajaksoja sisältävien, osatyökykyisille suunnattujen palvelujen ja työnantajien välistä yhteistyötä voidaan edistää työnantajien osallistumista lisäävillä ja yhteistyötä sujuvoittavilla strategioilla ja toimintatavoilla. Tällaisia ovat esimerkiksi soveltuva viestintä ja vuorovaikutus sekä kuntoutuksen ammattilaisen konsultoiva ote. Konsultoivan otteen mahdollistaa yritysten toimintaympäristöön ja -logiikkaan liittyvä ymmärrys. Tämä yhdistettynä työnhakijan tuntemukseen auttaa valmentajia löytämään eri osapuolia hyödyttäviä ratkaisuja. Näin valmentajan on mahdollista yhdistellä tarjonta- ja kysyntäpainotteisia lähestymistapoja (ks. Luecking 2008). Myös Härkäpään ym. (2013, 132) tutkimuksessa työhönvalmennukseen osallistuneet työnantajat näkivät tärkeäksi, että työhönvalmentaja tuntee sekä työpaikan toimialaa ja tehtäviä, että valmennettavan tarpeita, toiveita ja vahvuuksia. 
Tarjonta- ja kysyntäpainotteiset lähestymistavat ja niille perustuvat toimintatavat voidaankin nähdä toisiaan täydentävinä (Luecking, 2008). Kun toiminnan tarkoituksena on osatyökykyisten työllistymisen mahdollisuuksien edistäminen monipuolisin tavoin, ei strategioiden välillä tarvitse tehdä joko-tai valintaa. Esimerkiksi yhtäaikaiseen tukeen perustuvat ammatillisen kuntoutuksen lähestymistavat (support side approaches) (Frøyland ym. 2019b, 199) edustavat uudenlaista tapaa ymmärtää palvelu työnantajien ja kuntoutujien välisenä sovittajana (matchmaker), jolloin eri osapuolten välistä yhteistyötä rakennetaan yhdessä.

Aineiston perusteella yhteistyöhön liittyvien toimintatapojen on oltava työnantajien näkökulmasta luottamusta herättäviä, ja työnantajalle tulee tarjota tarvittavaa tukea. Pitkäjänteiset yhteistyösuhteet edistävät osaltaan luottamuksen syntymistä ja sopivan tuen tarjoamista. Näyttää siltä, että yhteistyösuhteen luomisessa on kyse tietynlaisen positiivisen kehän strategisesta alkuun saattamisesta ja tietoisesta ylläpidosta. Samaan aikaan kyse on henkilökohtaisista suhteista, luottamuksesta ja luovasta yhdessä toimimisesta.

Yritysten toimintaa ohjaavat taloudelliset tavoitteet ja tämä tulee ottaa yhteistyössä huomioon (esim. Alakauhaluoma ym. 2017). Molemminpuolisten hyötyjen varmistaminen liittyy siihen, ettei työnantajien osallistuminen palveluihin perustu ainoastaan hyväntekeväisyydelle tai sympatialle (Buys \& Rennie 2001). Tämänkaltaiset motiivit eivät välttämättä edistä pitkäjänteisesti osatyökykyisten työelämäinkluusiota. Kestävämmät motiivit voivat perustua taloudellisten hyötyjen lisäksi jaetuille arvoille ja niitä mukaileville käytännöille, kuten organisaatioiden diversiteettipolitiikalle ja monimuotoisen työvoiman rakentamiselle (esim. Harris ym. 2017) sekä yritysten yhteiskuntavastuulle (vrt. Kukkonen 2009).

Eräs katsauksen aihepiirin kannalta keskeinen kysymys on se, miten työnantajayhteistyötä voitaisiin tukea ja kehittää osana osatyökykyisten työllistymisen palveluja. Aineistossa huomio kiinnittyy esimerkiksi siihen, missä määrin esimiehet ymmärtävät työnantajayhteistyön merkityksen ja miten he käytännössä mahdollistavat sitä. Suomen kontekstissa työnantajayhteistyön toteuttaminen osana ammatillista kuntoutusta ja valmennuspalveluja on riippuvaista myös palvelujen järjestämistavoista, joissa valmennusta esimerkiksi ostetaan palveluntuottajilta henkilöasiakas kerrallaan. Kotimaisella kentällä voitaisiin pohtia pidemmälle sitä, millaisilla keinoilla sekä vastuu- ja maksukäytännöillä työnantajayhteistyön resursointi 
turvattaisiin (vrt. esim. Nupponen 2016). Esimerkiksi Nupponen $(2016,28)$ on esittänyt, ettei valmennuspalveluihin liittyvää korvausta tulisi myöntää vain henkilöasiakkaan ohjauksesta vaan “työnetsinnästä ja työhön kiinnittymisen varmistamisesta muutenkin kuin työn aloituksen

yhteydessä”. Keskeistä työnantajayhteistyön kehittämisessä on myös se, miten yhteistyötä voitaisiin järjestelmätasolla tukea ja resursoida siten, että työotteen mahdollisuudet ulottuisivat työhönvalmentajien arkityöhön.

Tässä katsauksessa hyödynnettiin aineistona eri lähtökohdista kirjoitettuja tekstejä ja erilaisilla metodeilla toteutettuja tutkimuksia. Aineiston luotettavuutta pohdittiin sekä aineiston valintaettä analyysivaiheessa. Aineiston tutkimuksiin sisältyi joitakin rajoituksia, ja osa teksteistä oli raportteja tai puheenvuoroja. Aineiston hakuvaiheessa tuli hyvin esiin se, että osatyökykyisten työllistymisen palveluiden kentällä tehdään runsaasti erilaisia selvityksiä, joilla on suuri merkitys käytännön kehittämistyön kannalta. Työnantajanäkökulmien tarkastelu on ollut vähäisempää. Selvityksissä tuotettu tieto saattaa myös jäädä hajanaiseksi, ja synteesien tekemiselle on tarvetta. Myös työnantajayhteistyön strategioiden ja toimintatapojen huolellista empiiristä koettelua tarvitaan lisää.

\section{Lähteet}

Alakauhaluoma M, Kesä M, Lehikoinen T, Pitkänen S, Ylikojola P (2017) Osatyökykyisistä osaavaa työvoimaa. Osatyökykyisten työvoiman kysyntää ja sen kehittämistä koskeva tutkimus. Työ- ja elinkeinoministeriö, Helsinki.

Anderson P (2001) The rehabilitation and employer partnership: Walking the walk. Journal of Vocational Rehabilitation 16, 2, 105 - 109. (aineisto)

Buys N, Rennie J (2001) Developing relationships between vocational rehabilitation agencies and employers. Rehabilitation Counseling Bulletin 44, 2, 95 - 103. (aineisto)

Braun V, Clarke V (2006) Using thematic analysis in psychology. Qualitative Research in Psychology 3, 2, 77-101.

Capella McDonnall M, Crudden A (2015) Building relationships with businesses: recommendations from employers concerning persons who are blind/visually impaired. Journal of Rehabilitation 81, 3, 43 - 50. (aineisto)

Carlson L, Smith G, Mariscal ES, Rapp C, Holter M, Ko E, Kukla M, Fukui S (2018) The Comparative Effectiveness of a Model of Job Development versus Treatment as Usual. Best Practices in Mental Health 14, 2, 21 - 31. (aineisto) 
Castleberry A, Nolen A (2018) Thematic analysis of qualitative research data. Is it as easy as it sounds? Currents in Pharmacy Teaching and Learning 10, 6, 807-815.

Drake RE, Bond GR, Becker DR (2012) IPS supported employment: An evidence-based approach to supported employment. Oxford University Press, New York.

Ellenkamp J, Brouwers E, Embregts P, Joosen M, van Weeghel J (2016) Work environmentrelated factors in obtaining and maintaining work in a competitive employment setting for employees with intellectual disabilities: A systematic review. Journal of Occupational Rehabilitation, 26, 1, 56 - 69.

Fitzgerald SM \& Rumrill PD Jr. (2005) Quantitative alternatives to narrative reviews for understanding existing research literature. Work 24, 3, 317-323.

Frøyland K, Andreassen T, Innvær S (2019a) Contrasting supply-side, demand-side and combined approaches to labour market integration. Journal of Social Policy, 48, 2, 311 - 328.

Frøyland K, Schafft A, Spjelkavik Ø (2019b) Tackling increasing marginalization: can supportside approaches contribute to work inclusion. Teoksessa H Hvid, E Falkum (toim.) Work and Wellbeing in the Nordic Countries: Critical Perspectives on the World's Best Working Lives. Taylor \& Francis, London.

Fry R, Toim. (1997) Developing Effective Partnerships with Employers as a Service Delivery Mechanism. Report from the Institute on Rehabilitation Issues Study Group, Washington, DC. https://files.eric.ed.gov/fulltext/ED418528.pdf [Luettu 12.6.2020]. (aineisto)

Grant M, Booth A (2009) A typology of reviews: an analysis of 14 review types and associated methodologies. Health Information and Libraries Journal, 26, 91-108.

Griffin G, Hammis D, Geary T, Sullivan M (2008) Customized employment: Where we are; where we're headed. Journal of Vocational Rehabilitation 28, 3, 135 - 139. (aineisto)

Harris C, Switzer E, Gower WS (2017) The diversity partner project: Multi-systemic knowledge translation and business engagement strategies to improve employment of people with disabilities. Journal of Vocational Rehabilitation 46, 3, 273 - 285. (aineisto)

Henry AD, Petkauskos K, Stanislawzyk J, Vogt J (2014) Employer-recommended strategies to increase opportunities for people with disabilities. Journal of Vocational Rehabilitation 41, 3, 237 - 248. (aineisto)

Hopia H, Latvala E, Liimatainen L (2016) Reviewing the methodology of an integrative review. Scandinavian Journal of Caring Sciences 30, 4, 662-669.

Härkäpää K, Harkko J, Lehikoinen T (2013) Työhönvalmennus ja sen kehittämistarpeet. Kela, Sosiaali- ja terveysturvan tutkimuksia 128. Kela, Helsinki. 
Härkäpää K, Järvikoski A (2013) Yhteenvetoa ja arviointia. Teoksessa AM Arola, K Härkäpää, A Järvikoski (toim.) Työtä tavoittelemassa. Ammatillisen kuntoutuksen projekti tarkastelun kohteena. Lapin yliopisto, Rovaniemi.

Järvikoski A, Härkäpää K (2004) Kuntoutuksen perusteet. WSOY, Helsinki.

Karhu J (2013) Vajaakuntoisten henkilöiden työllistäminen ja tuetun työllistymisen merkitys työnantajien näkökulmasta. Teoksessa AM Arola, K Härkäpää, A Järvikoski (toim.) Työtä tavoittelemassa. Ammatillisen kuntoutuksen projekti tarkastelun kohteena. Lapin yliopisto, Rovaniemi.

Kukla M, McGuire A, Strasburger A, Belanger E, Bakken S (2018) Helping veterans achieve work: a veterans health administration nationwide survey examining effective job development practices in the community. Psychiatric Rehabilitation Journal 41, 2, 103-108. (aineisto)

Kukkonen T (2009) Vastuun uusjako: Vajaakuntoisten työkyky ja työllistyminen yritysten näkökulmasta. Yhteiskuntatieteellisiä julkaisuja nro 102. Väitöskirja. Joensuu, Joensuun yliopisto, Yhteiskunta- ja aluetieteiden tiedekunta. http://urn.fi/URN:ISBN:978-952-219-301-8 [Luettu 12.6.2020].

Lexén A, Emmelin M, Bejerholm U (2016) Individual placement and support is the keyhole. Employer experiences of supporting persons with mental illness. Journal of Vocational Rehabilitation, 44, 2, 135 - 147.

Luecking R (2008) Emerging employer views of people with disabilities and the future of job development. Journal of Vocational Rehabilitation 29, 1, 3 - 13. (aineisto)

Moore D, Haines K, Bradshaw H, Porter A, Smith J, Foley S (2018) Development of the Progressive Employment dual customer model for vocational rehabilitation. Journal of Vocational Rehabilitation 49, 2, 149-160.

Nupponen M (2016) Teoksessa S Pikkusaari, P Ora ym. (toim.) Tuettu työllistyminen käytännössä. Kiipulan ammattiopisto.

Owens-Johnson L, Hanley-Maxwell C (1999) Employer views on job development strategies for marketing supported employment. Journal of Vocational Rehabilitation 12, 2, 113-123. (aineisto)

Pikkusaari S (2016) Tuettu työllistyminen - Mitä SE tarkoittaa? Teoksessa S Pikkusaari, P Ora ym. (toim.) Tuettu työllistyminen käytännössä. Kiipulan ammattiopisto.

Polit DF \& Beck CT (2012) Nursing research. Generating and assessing evidence for nursing practice. Ninth Edition. Lippincott Williams \& Wilkins, Philadelphia.

Post M, Campbell C, Heinz T, Kotsonas L, Montgomery J, Storey K (2010) Collaboration between supported employment and human resource services: strategies for success. Research \& Practice for Persons with Severe Disabilities 35, 1/2, 24 - 30. (aineisto) 
Publications Office of the EU (2012) Supported Employment for people with disabilities in the EU and EFTA-EEA. Good practices and recommendations in support of a flexicurity approach Study. European Union. https://op.europa.eu/s/n8fL [Luettu 18.6.2020].

Raivio H, Appelqvist-Schmidlechner K (2020) IPS - Sijoita ja valmenna! -kehittämishanke: Ohjelma. Sosiaali- ja terveysministeriön julkaisuja 2020:12. Sosiaali- ja terveysministeriö, Helsinki.

Raivio H, Appelqvist-Schmidlechner K (2019) IPS - Sijoita ja valmenna! -toimintamallin soveltamisen mahdollisuudet Suomessa. Terveyden ja hyvinvoinnin laitos, Työpaperi 23/201. Terveyden ja hyvinvoinnin laitos, Helsinki.

Riesen T, Morgan R (2018) Employer views of customized employment: A focus group analysis. Journal of Vocational Rehabilitation 49, 1, 33 - 44. (aineisto)

Rother ET (2007) Systematic literature review x narrative review. Editoria. Acta Paulista de Enfermagem 20, 2, vii.

Simmons T, Flexer R (1992) Business and rehabilitation factors in the development of supported employment programs for adults with developmental disabilities. Journal of Rehabilitation 58, 1, 35. (aineisto)

Simonsen M, Fabian E, Buchanan L, Luecking R (2011) Strategies used by employment service providers in the job development process: Are they consistent with what employers want? New Jersey DiscoverAbility project. https://www.issuelab.org/resources/6076/6076.pdf [Luettu 12.6.2020]. (aineisto)

Strindlund L, Abrandt-Dahlgren M, Ståhl C (2019) Employers’ views on disability, employability, and labor market inclusion: a phenomenographic study. Disability and Rehabilitation 41, 24, 2910 - 2917. (aineisto)

Swanson S, Becker D, Bond G (2013) Job development guidelines in supported employment. Psychiatric Rehabilitation Journal 36, 2, 122 - 123. (aineisto)

Tamburo J, Switzer E, Gower W (2019) Lessons from the Diversity Partners Project: Using knowledge translation to strengthen business engagement strategies and improve employment outcomes for job seekers with disabilities. Journal of Vocational Rehabilitation 50, 3, 291 - 299. (aineisto)

Torraco R (2016) Writing integrative literature reviews: using the past and present to explore the future. Human Resource Development Review 15, 4, 404 - 428.

Unger D (2007) Addressing employer personnel needs and improving employment training, job placement and retention for individuals with disabilities through public-private partnership.

Journal of Vocational Rehabilitation 26, 1, 39 - 48. (aineisto)

Whittemore R, Knafl K (2005) The integrative review: updated methodology. Journal of Advanced Nursing 52, 5, 546-553. 
Liitetaulukko 1: Aineiston julkaisut

\begin{tabular}{|c|c|c|c|}
\hline Tekijä(t) ja julkaisuvuosi & Nimi & Aihe & Tekstityyppi ja mahdollinen aineisto \\
\hline Anderson P. 2001 & $\begin{array}{l}\text { The rehabilitation and employer } \\
\text { partnership: Walking the walk }\end{array}$ & $\begin{array}{l}\text { Markkinoinnin perusperiaatteiden soveltaminen } \\
\text { ammatillisen kuntoutuksen organisaatioiden } \\
\text { henkilökunnan ja liikemaailman väliseen } \\
\text { kumppanuussuhteeseen }\end{array}$ & Katsaus, puheenvuoromaisia piirteitä \\
\hline Buys N. J. , Rennie J. 2001 & $\begin{array}{l}\text { Developing Relationships Between } \\
\text { Vocational Rehabilitation Agencies } \\
\text { and Employers }\end{array}$ & $\begin{array}{l}\text { Työantajien ja ammatillisen kuntoutuksen } \\
\text { palveluntuottajien välinen suhde ja tämän suhteen } \\
\text { luomista, kehittämistä ja ylläpitoa tukevat tekijät }\end{array}$ & $\begin{array}{l}\text { Empiirinen tutkimus, haastattelut (työnantajat } n=5 \text {, } \\
\text { palveluntuottajat } n=5 \text { ) (Australia) }\end{array}$ \\
\hline $\begin{array}{l}\text { Capella McDonnall M., } \\
\text { Crudden A. } 2015\end{array}$ & $\begin{array}{l}\text { Building Relationships with } \\
\text { Businessess: Recommendations from } \\
\text { Employers Concerning persons who } \\
\text { are Blind/Visually Impaired. }\end{array}$ & $\begin{array}{l}\text { Näkövammaisia palkanneiden työnantajien näkemykset } \\
\text { heidän suhteestaan ammatillisen kuntoutuksen } \\
\text { palveluntuottajaan }\end{array}$ & $\begin{array}{l}\text { Empiirinen tutkimus, työnantajahaastattelut }(\mathrm{n}=13) \\
\text { (USA) }\end{array}$ \\
\hline $\begin{array}{l}\text { Carlson L., Smith G., } \\
\text { Mariscal E., Rapp C., Holter } \\
\text { M., Ko E., Kukla M., Fukui S. } \\
2018\end{array}$ & $\begin{array}{l}\text { The Comparative Effectiveness of a } \\
\text { Model of Job Development versus } \\
\text { Treatment as Usual. }\end{array}$ & $\begin{array}{l}\text { Tietyn myyntimetodin tehokkuus job development - } \\
\text { prosessissa }\end{array}$ & $\begin{array}{l}\text { Empiirinen tutkimus, kvasikokeellinen asetelma (15 } \\
\text { työelämän asiantuntijaa, } 12 \text { vertailuryhmän jäsentä) }\end{array}$ \\
\hline Fry R. 1997 & $\begin{array}{l}\text { Developing Effective Partnerships } \\
\text { with Employers as a Service } \\
\text { Delivery Mechanism. }\end{array}$ & $\begin{array}{l}\text { Liittovaltion järjestämän/julkisen ammatillisen } \\
\text { kuntoutuksen ja yksityisen sektorin välisen } \\
\text { kumppanuussuhteen vahvistamiseen suunnitellut } \\
\text { lähestymistavat }\end{array}$ & Kuvaileva raportti (USA) \\
\hline $\begin{array}{l}\text { Griffin G., Hammis D., Geary } \\
\text { T., Sullivan M. } 2008 .\end{array}$ & $\begin{array}{l}\text { Customized employment: Where we } \\
\text { are; where we're headed }\end{array}$ & $\begin{array}{l}\text { Customized employment- toimintamallin periaatteet ja } \\
\text { tulevaisuus }\end{array}$ & Puheenvuoro \\
\hline $\begin{array}{l}\text { Harris C., Switzer E., Gower } \\
\text { W. S. } 2017 \\
\end{array}$ & $\begin{array}{l}\text { The diversity partner project: Multi- } \\
\text { systemic knowledge translation and } \\
\text { business engagement strategies to } \\
\text { improve employment of people with } \\
\text { disabilities }\end{array}$ & $\begin{array}{l}\text { Työllistymispalveluiden ammattilaisten ja työnantajien } \\
\text { välisen suhteen kehittämiseen suunnatun intervention } \\
\text { kehittämisprojektin kuvaaminen }\end{array}$ & $\begin{array}{l}\text { Intervention kehittämisprojektin tapauskuvaus } \\
\text { (USA) }\end{array}$ \\
\hline \begin{tabular}{|l|} 
Henry A. D., Petkauskos K., \\
Stanislawzyk J., Vogt, J. 2014 \\
\end{tabular} & $\begin{array}{l}\text { Employer-recommended strategies to } \\
\text { increase opportunities for people } \\
\text { with disabilities }\end{array}$ & $\begin{array}{l}\text { Osatyökykyisten palkkaamiseen liittyvät haasteet ja } \\
\text { ratkaisut }\end{array}$ & $\begin{array}{l}\text { Empiirinen tutkimus, työnantajien } \\
\text { fokusryhmähaastattelut }(\mathrm{n}=74) \text { (USA) }\end{array}$ \\
\hline $\begin{array}{l}\text { Kukla M., McGuire A., } \\
\text { Strasburger A., Belanger E., } \\
\text { Bakken S. } 2018\end{array}$ & $\begin{array}{l}\text { Helping Veterans Achieve Work: A } \\
\text { Veterans Health Administration } \\
\text { Nationwide Survey Examining } \\
\text { Effective Job Development Practices } \\
\text { in the Community }\end{array}$ & $\begin{array}{l}\text { Tehokkaat job development-käytännöt ja palvelut } \\
\text { veteraaneille suunnatuissa ammatillisen kuntoutuksen } \\
\text { palveluissa }\end{array}$ & $\begin{array}{l}\text { Empiirinen tutkimus, monimenetelmällinen online- } \\
\text { survey ammatillisen kuntoutuksen palveluntuottajille } \\
(\mathrm{n}=233) \text { (USA) }\end{array}$ \\
\hline Luecking R. 2008 & $\begin{array}{l}\text { Emerging employer views of people } \\
\text { with disabilities and the future of job } \\
\text { development }\end{array}$ & $\begin{array}{l}\text { Työnantajien näkökulma suhteessa dual customer and } \\
\text { demand-side job development -paradigmoihin sekä } \\
\text { näkökulman merkitys job development - käytäntöjen } \\
\text { kannalta }\end{array}$ & Katsaus, puheenvuoromaisia piirteitä \\
\hline $\begin{array}{l}\text { Owens-Johnson L., Hanley- } \\
\text { Maxwell C. } 1999\end{array}$ & $\begin{array}{l}\text { Employer views on job development } \\
\text { strategies for marketing supported } \\
\text { employment }\end{array}$ & $\begin{array}{l}\text { Työnantajien preferoimat tuetun työllistymisen } \\
\text { markkinointistrategiat ja preferensseihin vaikuttavat } \\
\text { tekijät }\end{array}$ & $\begin{array}{l}\text { Empiirinen tutkimus, survey työnantajille }(\mathrm{n}=934) \\
\text { (USA) }\end{array}$ \\
\hline $\begin{array}{l}\text { Post M., Campbell C., Heinz } \\
\text { T., Kotsonas L., Montgomery } \\
\text { J., Storey K. } 2010\end{array}$ & $\begin{array}{l}\text { Collaboration Between Supported } \\
\text { Employment and Human Resource } \\
\text { Services: Strategies for Success. } \\
\end{array}$ & $\begin{array}{l}\text { Henkilöstöjohtajien ja tuetun työllistymisen } \\
\text { palveluntuottajien välisen yhteistyön edut ja yhteistyön } \\
\text { strategiat }\end{array}$ & $\begin{array}{l}\text { Monitapaustutkimus, yksi julkisen ja yksi yksityisen } \\
\text { sektorin case (USA) }\end{array}$ \\
\hline $\begin{array}{l}\text { Riesen T., Morgan R. L. } \\
2018 .\end{array}$ & $\begin{array}{l}\text { Employer views of customized } \\
\text { employment: A focus group analysis }\end{array}$ & $\begin{array}{l}\text { Työnantajien näkemykset customized employment - } \\
\text { prosessin esteistä ja fasilitaattoreista }\end{array}$ & $\begin{array}{l}\text { Empiirinen tutkimus, online-fokusryhmähaastattelut } \\
\text { työnantajille }(\mathrm{n}=10) \text { (USA) }\end{array}$ \\
\hline Simmons T., Flexer R. 1992 & $\begin{array}{l}\text { Business and rehabilitation factors in } \\
\text { the development of supported } \\
\text { employment programs for for adults } \\
\text { with developmental disabilities }\end{array}$ & $\begin{array}{l}\text { Työnantajien osallistaminen tuettuun työllistämiseen } \\
\text { (aikuiset, joilla kehityksellisiä häiriöitä) liikemaailman } \\
\text { käsitteitä sekä kannustimia käyttämällä }\end{array}$ & Katsaus, puheenvuoromaisia piirteitä \\
\hline $\begin{array}{l}\text { Simonsen M., Fabian E. S., } \\
\text { Buchanan L., Luecking R. } \\
2011\end{array}$ & $\begin{array}{l}\text { Strategies used by employment } \\
\text { service providers in the job } \\
\text { development process: Are they } \\
\text { consistent with what employers } \\
\text { want? }\end{array}$ & $\begin{array}{l}\text { Työllistymispalvelujen ammattilaisten sekä työn } \\
\text { etsijöiden/kehittäjien (job developers) strategiat } \\
\text { työllistämisprosessissa suhteessa työnantajien } \\
\text { näkökulmaan }\end{array}$ & $\begin{array}{l}\text { Empiirinen tutkimus, fokusryhmät ammatillisen } \\
\text { kuntoutuksen ammattilaisille }(n=48) \text { ja suppea } \\
\text { kirjallisuuskatsaus (USA) }\end{array}$ \\
\hline $\begin{array}{l}\text { Strindlund L., Abrandt- } \\
\text { Dahlgren M., Ståhl C. } 2019\end{array}$ & $\begin{array}{l}\text { Employers' views on disability, } \\
\text { employability, and labor market } \\
\text { inclusion: a phenomenographic study }\end{array}$ & $\begin{array}{l}\text { Työnantajien näkemykset osatyökykyisten } \\
\text { työllistettävyydestä ja osatyökykyisten } \\
\text { työmarkkinainkluusiosta }\end{array}$ & $\begin{array}{l}\text { Empiirinen, fenomenografinen tutkimus, } \\
\text { työnantajahaastattelut ( } \mathrm{n}=27) \text { (Ruotsi) }\end{array}$ \\
\hline $\begin{array}{l}\text { Swanson S., Becker D. R., } \\
\text { Bond, G. R. } 2013\end{array}$ & \begin{tabular}{|l|}
$\begin{array}{l}\text { Job development guidelines in } \\
\text { supported employment }\end{array}$ \\
\end{tabular} & Työnantajasuhteiden rakentamisen metodit & $\begin{array}{l}\text { Henkilökohtaisiin havaintoihin ja kirjallisuuteen } \\
\text { pohjautuva teksti (brief report) }\end{array}$ \\
\hline $\begin{array}{l}\text { Tamburo J., Switzer E., } \\
\text { Gower W. S. } 2019\end{array}$ & $\begin{array}{l}\text { Lessons from the Diversity Partners } \\
\text { Project: Using knowledge translation } \\
\text { to strengthen business engagement } \\
\text { strategies and improve employment } \\
\text { outcomes for job seekers with } \\
\text { disabilities. }\end{array}$ & $\begin{array}{l}\text { Toimintatapa "knowledge translation activities" } \\
\text { työantajien osallistamisen interventiossa; erityisesti } \\
\text { kapasiteetin rakentamisen rooli }\end{array}$ & Intervention tapauskuvaus (USA) \\
\hline Unger D. 2007 & $\begin{array}{l}\text { Addressing employer personnel } \\
\text { needs and improving employment } \\
\text { training, job placement and retention } \\
\text { for individuals with disabilities } \\
\text { through public-private partnership } \\
\end{array}$ & $\begin{array}{l}\text { Työnantajien ja työllistymispalveluiden suhde, } \\
\text { työnantajien yhteistyöhalukkuutta lisäävät tekijät ja } \\
\text { toimivan kumppanuuden osatekijät }\end{array}$ & $\begin{array}{l}\text { Tapauskuvaus, kaksi kuvausta julkinen-yksityinen- } \\
\text { kumppanuussuhteesta (USA) }\end{array}$ \\
\hline
\end{tabular}

